\title{
Procedural Due Process Rights of Pro Se Civil Litigants
}

\author{
Julie M. Bradlow $\dagger$
}

An indigent person files a claim in federal district court under 42 U.S.C. $\S 1983$. He requests both leave to proceed in forma pauperis-without liability for court costs-under 28 U.S.C. $\S$ 1915(a) and court-appointed counsel under 28 U.S.C. $\S 1915(d)$. The court grants leave to proceed but denies his request for counsel. Shortly thereafter, the defendant in the action, represented by counsel, files a motion for summary judgment under Rule 56 of the Federal Rules of Civil Procedure. The plaintiff is served with the motion, but because he does not comprehend it, he does not respond to it, assuming that he can address the motion at trial. The judge then automatically enters summary judgment against the pro se plaintiff. The pro se plaintiff learns of this dismissal and files an appeal, claiming that the trial court should have given him an explanation as to the meaning of a summary judgment motion. Is he correct? At present, the answer depends upon the court in which he sued. This also is true with regard to many other procedural blunders-besides failure to respond to a summary judgment motion-that pro se civil litigants who are untrained in the law may make.

How should courts treat pro se litigants? Although the United States Supreme Court has not confronted directly the question whether pro se civil litigants should be assisted throughout trial, the Court indicated in dicta in Faretta $v$. California ${ }^{1}$ that courts should not excuse pro se criminal litigants from compliance with procedural requirements. The Supreme Court itself has treated this dicta as settled law in subsequent cases, and lower federal courts have followed it as well. This comment takes the position that the rule derived from Faretta-stating that pro se criminal litigants should get no special treatment-is constitutionally correct if limited to criminal cases.

Currently, procedural treatment of pro se civil litigants is at

$\dagger$ B.A. 1985, Yale University; J.D. Candidate 1988, The University of Chicago.

1422 U.S. 806, 835 n.46 (1975). 
best highly case-specific, at worst inconsistent. ${ }^{2}$ This comment concludes that a discretionary regime should be preserved, in the sense that the question of how much process is due in any given case should be resolved by means of a sliding scale. The leniency automatically due a pro se litigant simply because he or she is proceeding pro se is, in general, that which courts already grant: in particular, pro se litigants are entitled to have their pleadings liberally construed by the courts. A liberal construction of the pleadings enables a court to assess the nature of the interests at stake in the suit and to determine how much further procedural leniency, if any, is due in the particular case.

This comment is divided into three sections. The first section provides a brief overview of pro se litigation. The second section discusses the Supreme Court's dicta on treatment of pro se litigants and the constitutional justifications for this position in criminal cases. The third section discusses procedural treatment of civil litigants. It first presents some examples of current treatment of pro se civil litigants and proposals made in the past for alleviating their plight. It then applies current due process jurisprudence and argues that the Supreme Court's current test for how much process the due process clause of the fifth amendment requires demands a more individualized determination than afforded in these approaches. It is a balancing test which becomes, when applied across the board, a sliding scale. At a minimum, this scale will require that, as the law presently provides, pro se pleadings must be liberally construed. Beyond this rule of liberal construction, the sliding scale offers pro se litigants only the guarantee that judges will endeavor to give such leniency and special attention as the particular case merits.

\section{An Overview of Pro Se Litigation}

The sixth amendment guarantees to criminal defendants the right to assistance of counsel. Criminal defendants do, however, have the right to waive such assistance and appear pro se. ${ }^{3}$ In civil

${ }^{2}$ See Donald H. Zeigler and Michele G. Hermann, The Invisible Litigant: An Inside View of Pro Se Actions in the Federal Courts, 47 N.Y.U.L.Rev. 157, 160 (1972) (since pro se litigants often are unable to comply with procedural rules, exceptions are carved out in practice).

${ }^{3}$ Faretta, 422 U.S. at 819-20. For important cases developing the right-to-counsel jurisprudence, see Powell v. Alabama, 287 U.S. 45 (1932); Johnson v. Zerbst, 304 U.S. 458 (1938); Gideon v. Wainwright, 372 U.S. 335 (1963); Argersinger v. Hamlin, 407 U.S. 25 (1972). See also Comment, Constitutional Law: The Sixth Amendment Right of Self-Representation and the Role of Standby Counsel, 24 Washburn L.J. 164 (1984); Michele Hermann and 
cases, litigants have a statutory right, first embodied in the Judiciary Act of 1789 , to represent themselves. ${ }^{4}$ Most states also provide, either by constitution or by statute, for a right of self-representation in state courts. ${ }^{\circ}$

One wonders, of course, given the labyrinthine nature of the court system, let alone the labyrinthine nature of the law, why anyone would choose to appear pro se. The saying goes that "one who is his own lawyer has a fool for a client." It is the perils of self-representation that lie behind the sixth amendment right to counsel in the first place. In Powell v. Alabama, ${ }^{7}$ an early right to counsel case, the Supreme Court wrote:

Even the intelligent and educated layman has small and sometimes no skill in the science of law. . . . He lacks both the skill and knowledge adequately to prepare his defense, even though he have [sic] a perfect one. He requires the guiding hand of counsel at every step in the proceedings against him. Without it, though he be not guilty, he faces the danger of conviction because he does not know how to establish his innocence. If that be true of men of intelligence, how much more true is it of the ignorant and illiterate, or those of feeble intellect. ${ }^{8}$

Nonetheless, many criminal defendants elect to represent themselves for a variety of reasons. Some believe that the public defender's office could not satisfactorily defend them because of its large caseload. ${ }^{9}$ Others harbor either a mistrust of counsel ${ }^{10}$ or a blind faith in their own innocence and a belief that courts will do

Shannon Donahue, Fathers Behind Bars: The Right to Counsel in Civil Contempt Proceedings, 14 N.M.L.Rev. 275, 289-91 (1984).

1 Stat. 73, 92 (1789). Similar language is codified at 28 U.S.C. $\$ 1654$ (1982).

s See Note, Legal Education for the Pro Se Litigant: A Step Towards a Meaningful Right To Be Heard, 96 Yale L.J. 1641, 1641 n.2 (1987)(listing state statutes and constitutional provisions).

- Faretta, 422 U.S. at 852 (Blackmun dissenting).

287 U.S. 45 (1932).

- Id. at 69. Other courts have put it in even blunter fashion. See, e.g., United States v. Dujanovic, 486 F.2d 182, 186 (9th Cir. 1973) (a pro se litigant ranges "from the misguided or naive who just wants to tell the jury the truth, through the pressured one under the hardships of the accusation of crime and the sophisticated person enamored with his own ability, to the crafty courtroom experienced one who ruthlessly plays for the breaks. All eventually play the part of the proverbial fool.").

- Ira P. Robbins and Susan N. Herman, Pro Se Litigation - Litigating Without Counsel: Faretta or For Worse, 42 Brooklyn L.Rev. 629, 632 (1976).

${ }^{10}$ Id. 
what is right. ${ }^{11}$ Yet others feel that they have a personal stake in the outcome that an attorney will not. ${ }^{12}$ Some simply feel that justice has not been served in their case. ${ }^{13}$ Finally, many pro se litigants choose this route for reasons of trial strategy. Some hope to invoke the jury's sympathy by creating the plaintive image of the "lone defendant against the mammoth state;" others hope that by appearing without counsel, they will seem more credible because the jury will judge them as people. ${ }^{15}$

Many pro se civil litigants doubtless represent themselves for some of the reasons applicable to criminal defendants. Others appear pro se because they cannot afford counsel. Because the Supreme Court has held that there is no absolute due process right to counsel in civil cases, ${ }^{16}$ indigent pro se civil litigants face not only the unlikelihood of receiving court-appointed counsel, but other obstacles as well.

Indigent civil litigants must file for leave to proceed without liability for court costs under 28 U.S.C. $\S 1915(\mathrm{a}) .{ }^{17}$ If this leave is granted, they then can request appointment of counsel under 28 U.S.C. $\S 1915(d){ }^{18}$ Appointment of counsel in these cases is at the court's discretion, however. Generally, it will occur only in exceptional circumstances. ${ }^{19} \mathrm{~A}$ court, however, may be more willing to

1 Recent Development, The Role of Standby Counsel: The Road From Faretta to Wiggins, 27 How.L.J. 1799, 1799 (1984).

12 Id.

13 Zeigler and Hermann, 47 N.Y.U.L.Rev. at 163 (cited in note 2).

14 Wiggins v. Estelle, 681 F.2d 266, 271 n.16 (5th Cir. 1982).

18 Recent Development, 27 How.L.J. at 1800 (cited in note 11).

${ }^{16}$ Lassiter v. Department of Social Services, 452 U.S. 18, 26-27 (1981)(adopting a presumption that there is, absent a potential deprivation of the litigant's physical liberty, no due process right to counsel; moreover, in civil cases, the other elements in the due process decision must be weighed against this presumption when deciding whether to appoint counsel). The "other elements" to which the Court refers in Lassiter are the factors incorporated into the due process balancing test in Mathews v. Eldridge, 424 U.S. 319, 335 (1976), discussed in section III.B.

1728 U.S.C. $\& 1915$ (a) (1982) provides:

Any court of the United States may authorize the commencement, prosecution or defense of any suit, action or proceeding, civil or criminal, or appeal therein, without prepayment of fees and costs or security therefor, by a person who makes affidavit that he is unable to pay such costs or give security therefor. Such affidavit shall state the nature of the action, defense or appeal and affiant's belief that he is entitled to redress. 18 28 U.S.C. § 1915 (d) (1982) provides:

The court may request an attorney to represent any such person unable to employ counsel and may dismiss the case if the allegation of poverty is untrue, or if satisfied that the action is frivolous or malicious.

${ }^{19}$ See, e.g., Miller v. Simmons, 814 F.2d 962, 966 (4th Cir. 1987); Wilborn v. Escalderon, 789 F.2d 1328, 1331 (9th Cir. 1986); Aldabe v. Aldabe, 616 F.2d 1089, 1093 (9th Cir. 1980). Some circuits have adopted less demanding tests. See, e.g., Hodge v. Police Of- 
appoint counsel for the pro se defendant in a civil case than for the pro se plaintiff. Whether the requisite circumstances exist in a given instance depends on the complexity of the legal issues involved and the perceived ability of the pro se litigant to prepare and bring his case. ${ }^{20}$ Some courts have added a third requirement: that a claim be "colorable," that is, have a likelihood of success on the merits. ${ }^{21}$

Indigent civil litigants seeking to proceed under $\S 1915$ also must avoid having their actions dismissed under $\S 1915(\mathrm{~d})$ as "frivolous or malicious."22 Some commentators have argued that $\S$ 1915(d) review actually is separable from the merits of the case, and not an additional stage of on-the-merits review before pleadings are filed and argument is heard-to which criminal defendants and non pro se civil litigants are not subjected. ${ }^{23}$ Regardless of the answer to this point of procedural arcana, it is clear that $\S$ 1915(d) review provides a potential opportunity for cursory treatment of a meritorious pro se complaint. With $\S 1915(\mathrm{~d})$ review, the danger exists that courts will arbitrarily dismiss meritorious complaints because judges do not read them with the tolerance due pro se pleadings. Few jurisdictions require courts to state their reasons for dismissal under $\S 1915(\mathrm{~d}){ }^{24}$ Moreover, courts tend erroneously to consider the dismissal issue together with, instead of after, the issue of whether the plaintiff has leave to proceed in forma pauperis in the first place under 28 U.S.C. § 1915(a). This creates the possibility that a court may dismiss a case without opinion

ficers, 802 F.2d 58, 60-61 (2d Cir. 1986)(factors that point in favor of appointing counsel: likelihood of success on the merits, need for detailed investigation, presence of important credibility issues, pro se litigant's ability, and complex legal issues); Maclin v. Freake, 650 F.2d 885, 887-88 (7th Cir. 1981)(same).

${ }^{20}$ See, e.g., Cookish v. Cunningham, 787 F.2d 1, 2-3 (1st Cir. 1986); Robbins v. Maggio, 750 F.2d 405, 412 (5th Cir. 1985); Branch v. Cole, 686 F.2d 264, 266 (5th Cir. 1982).

${ }^{21}$ See, e.g., United States v. 30.64 Acres of Land, 795 F.2d 796, 800 n.8 (9th Cir. 1986); Whisenant v. Yuam, 739 F.2d 160, 163 (4th Cir. 1984).

2228 U.S.C. $\$ 1915$ (d) (1982). Courts construing pleadings pursuant to this statute use the same lenient standard applicable to construction of pro se pleadings in a fuller proceeding on the merits. See Haines v. Kerner, 404 U.S. 519 (1972), discussed in section III.A.

${ }^{23}$ See Robbins and Herman, 42 Brooklyn L.Rev. at 664-68 (cited in note 9) (\$ 1915(d) review is separable from the merits of the case). See also Note, Denial of a Pro Se Litigant's Motion to Appoint Counsel: The Preclusive Effect of Refusing Immediate Review, 50 Fordham L.Rev. 1399, 1411 (1982) (arguing that denial of motion to appoint counsel should be immediately appealable).

24 Crisafi v. Holland, 655 F.2d 1305, 1310 (D.C.Cir. 1981). See also The Federal Judicial Center's Prisoner Civil Rights Committee, Recommended Procedures for Handling Prisoner Civil Rights Cases in the Federal Courts 7 (1980)("Recommended Procedures") (high volume of prisoner condition-of-confinement cases and the large number of frivolous complaints makes it difficult to ensure that the meritorious case will be recognized). 
even before formally docketing it. $^{28}$

Under the current system, a court might deny a pro se civil litigant counsel and then-assuming that the pro se litigant's case is not immediately dismissed under $\S 1915(\mathrm{~d})$-hold the pro se litigant to the same standards of compliance with procedural rules as a litigant with counsel, even though the pro se litigant did not choose to appear pro se. Since he will have difficulty complying with these rules, he risks losing his case on relatively mundane procedural issues. Moreover, the possibility exists, although at least in theory it is not supposed to happen, that a pro se litigant who has a substantive cause of action may suffer dismissal under $\S 1915(\mathrm{~d})$ or other pleading rules, such as Rule 12(b)(6) of the Federal Rules of Civil Procedure, through omission of facts or ignorance of the law. ${ }^{26}$ These possibilities raise the question whether the procedural treatment currently given the pro se civil litigant by the federal courts comports with due process or whether more leniency is required to preserve the litigant's meaningful opportunity to be heard. ${ }^{27}$ This comment will take up this question in section three; first, however, this comment discusses and defends the current treatment of pro se criminal defendants.

\section{Procedural Treatment of Pro Se Litigants in Criminal CASES}

In Faretta $v$. California, ${ }^{28}$ the Supreme Court found implicit in the right to counsel clause of the sixth amendment a right to self-representation in criminal cases. The Court noted in dicta, however, that one who waives the benefit of legal representation does not relieve himself of the burden of compliance with procedural requirements. ${ }^{29}$ Both lower federal courts and commentators

${ }^{25}$ See Recommended Procedures at 57 (cited in note 24); Wayne T. Westling and Patricia Rasmussen, Prisoners' Access to the Courts: Legal Requirements and Practical Realities, 16 Loy.U.Chi.L.J. 273, 297-98 (1985).

${ }^{28}$ While the Supreme Court has held that pro se pleadings should be viewed with special care, see Haines v. Kerner, 404 U.S. 519 (1972), a litigant with counsel may allege crucial facts a pro se litigant would not think to include in his pleadings. Moreover, pleadings drafted by counsel not only may be phrased more artfully, but also may allege viable causes of action which might not occur to the pro se litigant, or for that matter, to the court. See Recommended Procedures at 13-14 (cited in note 24); Westling and Rasmussen, 16 Loy.U.Chi.L.J. at 309 (cited in note 25) (a good case can be lost by poor presentation).

${ }^{27}$ See Robbins and Herman, 42 Brooklyn L.Rev. at 641 (cited in note 9) (issue is not only whether a pro se litigant has claims of which he is unaware, but also whether it is the court's responsibility to help him find them).

${ }^{28} 422$ U.S. 806 (1975).

29 Id. at 835 n.46. 
have picked up this seemingly innocent footnote and given it the status of settled law. Yet despite its questionable genealogy, the rule has sufficient constitutional justifications if limited to criminal defendants.

In Faretta, the eponymous defendant was charged with grand theft. He sought permission from the court to represent himself at trial. Initially, the trial judge permitted Faretta to do so. Several weeks later, but still prior to trial, the court, on its own initiative, held a hearing to determine Faretta's competence to represent himself. After extensive questioning, the judge determined that Faretta had not made a knowing and intelligent waiver of his right to counsel and that he had no constitutional right to conduct his own defense. ${ }^{30}$ Faretta appealed his subsequent conviction on the ground that he should have been allowed to represent himself.

The Supreme Court granted certiorari and reversed. The very language of the sixth amendment, Justice Stewart wrote for the Court, grants rights to the defendant personally, "for it is he who suffers the consequences if [he] . . . fails,"31 and not to his counsel. Assistance of counsel, under this scheme, means just that and nothing more:

The language and spirit of the Sixth Amendment contemplate that counsel, like the other defense tools guaranteed by the Amendment, shall be an aid to a willing defendant-not an organ of the State interposed between an unwilling defendant and his right to defend himself personally. To thrust counsel upon the accused, against his considered wish, thus violates the logic of the Amendment. In such a case, counsel is not an assistant, but a master; and the right to make a defense is stripped of the personal character upon which the Amendment insists. ... Unless the accused has acquiesced in such representation, the defense presented is not the defense guaranteed him by the Constitution, for, in a very real sense, it is not his defense. ${ }^{32}$

The Court noted as well that the sixth amendment right to self-representation is reinforced by that amendment's roots in English legal history. ${ }^{33}$ The Court distinguished those cases recogniz-

so Id. at 808-10 and n.3.

31 Id. at $818-20$.

32 Id. at $820-21$.

3s Id. at 821-32. The Court discussed procedure in the seventeenth-century Star Chamber, where counsel was required, and one could not answer an indictment without counsel's signature, thus forcing an involuntary "confession" of sorts in some cases. It then discussed 
ing the right to court-appointed counsel from Faretta on the ground that although the Constitution may obligate the state to provide a requesting litigant with counsel, the state may not force a criminal defendant to accept a lawyer he does not want. ${ }^{34}$

After criminal defendants "knowingly and intelligently" waive the right to assistance of counsel, however, they relinquish the privileges of having counsel as well. ${ }^{35}$ The Court noted in Faretta that the unsuccessful pro se defendant may not claim ineffective assistance of counsel on appeal..$^{36}$ More importantly for present purposes, the Court remarked in dicta that:

The right of self-representation is not a license to abuse the dignity of the courtroom. Neither is it a license not to comply with relevant rules of procedural and substantive law. ${ }^{37}$

Justice Blackmun clearly intended his dissent in Faretta to cushion the impact of what supposedly was dicta upon future cases. The opinion of the majority, Blackmun wrote, was lacking in that:

[It left] open a host of other procedural questions . . . . I assume that many of these questions will be answered with finality in due course. Many of them, however, such as the ... treatment of the pro se defendant, will haunt the trial of every defendant who elects to exercise his right to selfrepresentation. $^{38}$

Despite Blackmun's admonitory conclusion that the Faretta Court had not reached any conclusion about the pro se criminal litigant's obligation to comply with procedural rules, in a subse-

the Treason Act of 1695 , which, in contravention to the existing practice of self-representation permitted (but did not require) assistance of counsel in treason cases. Although all felony defendants in England ultimately were given the right to counsel, lawyers were not forced upon them. In the colonies, the right of self-representation was never questioned; if anything, it was actively promoted, for many people distrusted lawyers. Many colonial charters and early state laws meticulously preserved this right. Moreover, the Court in Faretta noted the relationship of the Judiciary Act of 1789, which guarantees self-representation in civil cases, to the sixth amendment.

${ }^{34}$ Id. at $833-35$.

${ }^{36}$ Id. at $835-37$.

${ }^{36}$ Id. at 835 n.46. The test for whether counsel has been "ineffective" is whether or not counsel gave reasonably effective assistance. For a discussion of the history of this standard's development and the Supreme Court's landmark holding in Strickland v. Washington, 466 U.S. 668 (1984), see Comment, Constitutional Law: The Sixth Amendment Right to Effective Assistance of Counsel, 24 Washburn L.J. 360 (1985).

${ }^{37}$ Faretta, 422 U.S. at 835 n.46.

${ }^{38}$ Id. at 852 (Blackmun dissenting). 
quent case dealing with the right to self representation, the Court gave the Faretta dicta the status of settled law. In McKaskle $v$. Wiggins, ${ }^{39}$ the Court held that unsolicited participation of standby counsel did not impair the defendant Wiggins' Faretta rights, reasoning that standby counsel might provide the pro se litigant with needed assistance since the pro se status of a criminal defendant does not excuse the defendant from normal procedural rules:

Faretta rights are also not infringed when standby counsel assists the pro se defendant in overcoming routine procedural or evidentiary obstacles to the completion of some specific task ... that the defendant has clearly shown he wishes to complete. Nor are they infringed when counsel merely helps to ensure the defendant's compliance with basic rules of courtroom protocol and procedure. . . . A defendant does not have a constitutional right to receive personal instruction from the trial judge on courtroom procedure. Nor does the Constitution require judges to take over chores for a pro se defendant that would normally be attended to by trained counsel as a matter of course. Faretta recognized as much. ${ }^{10}$

In some instances, lower federal courts have, in both civil and criminal cases, explicitly followed the Faretta standard.11 In other cases, which do not cite Faretta, courts evidently have adhered to its reasoning. ${ }^{2}$ Some commentators also have considered this ap-

39 465 U.S. 168 (1984).

so Id. at $183-84$.

4 See, e.g., Andrews v. Bechtel Power Corp., 780 F.2d 124, 140 (1st Cir. 1985) (pro se plaintiff cannot be exempted from Fed.R.Evid. 103(a)(2), forbidding a claim of error predicated on evidence not actually offered at trial); Burgs v. Sissel, 745 F.2d 526, 528 (8th Cir. 1984) (pro se plaintiff cannot be excused from complying with the requirements of Fed.R.Civ.Proc. 41(b), case dismissed for failure to comply with order of court); Birl v. Estelle, 660 F.2d 592, 593 (5th Cir. 1981) (pro se plaintiff in habeas action cannot be excused from failure to take a timely appeal under Fed.R.App.Proc. 4(a)); Hepperle v. Johnston, 590 F.2d 609, 612-13 (5th Cir. 1979) (pro se plaintiff's failure to appear for deposition justified dismissal for want of prosecution under Fed.R.Civ.Proc. 41(b)); Martinez-McBean v. Government of Virgin Islands, 562 F.2d 908, 912-13 (3d Cir. 1977) (pro se status did not mitigate failure to comply with local period for appeal, thus lower court's reversal under Fed.R.Civ.Proc. 60(b)(6) not justified).

${ }^{42}$ See, e.g., Jacobsen v. Filler, 790 F.2d 1362, 1364-67 (9th Cir. 1986) (court has no duty to inform pro se plaintiff of need to respond to motion for summary judgment); Nelson v. Foti, 707 F.2d 170, 171-72 (5th Cir. 1983) (pro se plaintiff should not be excused from failure to take timely appeal under Fed.R.App.Proc. 4(a)); Dozier v. Ford Motor Co., 702 F.2d 1189, 1194-95 (D.C.Cir. 1983) (court was not wrong in dismissing pro se plaintiff's complaint for lack of jurisdiction even though complaint could have been amended); United States v. Pinkey, 548 F.2d 305, 310 (10th Cir. 1977) (pro se defendant was not denied a fair trial because he failed to object to judge's suggestion that plaintiff government introduce handwritten voir dire questions into evidence in mail fraud action). 
proach to be the last word on special treatment of pro se litigants. ${ }^{43}$ For dicta on an issue supposedly not before the Court, the Faretta standard has been given substantial deference.

Although the Court never has had the pro se procedural treatment question directly before it, the theory underlying the Faretta approach is generally accepted in the Court's sixth amendment right to counsel jurisprudence. The opinion of the Court in Wiggins shows that the issue of procedural compliance by pro se criminal defendants is viewed not only in terms of the pro se litigant's right to self-representation, but also in terms of the need to preserve the impartiality of the judge. Judicial impartiality was one of the original justifications for the sixth amendment right to counsel. ${ }^{44}$ The judge who unduly aids the pro se litigant in his defense is, it is argued, wrongfully acting as an advocate for one side of the dispute. ${ }^{48}$

According the pro se criminal defendant no special treatment obviously may deter some from exercising their right to self-representation or may encourage courts to appoint standby counsel more frequently. Despite the Court's observation in Faretta that the state cannot force a criminal defendant to accept a lawyer that he does not want, the Court's subsequent decision in Wiggins makes it clear that the right of self-representation is not so sacrosanct that courts may not do anything at all which affects it. Like appointment of counsel to represent an accused, appointment of standby counsel removes a potential obstacle to judicial impartiality. As long as the use of standby counsel preserves the jury's perception that the pro se defendant is conducting his own defense, the defendant's Faretta right of self-representation is not infringed. ${ }^{48}$ Hence, Wiggins shows that courts may address the impartiality problem in a manner not wholly favorable to the pro se criminal defendant. The federal courts may take an approach, then, which provides criminal defendants with an incentive to accept court-appointed counsel.

43 See, e.g., Comment, Pro Se Defendants and Advisory Counsel, 14 Land \& Water L.Rev. 227, 247-48 (1979); Paul Marcus, The Faretta Principle: Self-Representation v. the Right to Counsel, 30 Am.J.Comp.L. 551, 569-70 (1982 Supp.).

4 Powell v. Alabama, 287 U.S. 45, 61 (1932).

45 Jacobsen, 790 F.2d at 1365-66; Pinkey, 548 F.2d at 311 ("[T] obligation to become an 'advocate' for or to assist and guide the pro se layman through the trial thicket”); United States ex rel. Smith v. Pavich, 568 F.2d 33, 40 (7th Cir. 1978)(same). See also Robbins and Herman, 42 Brooklyn L.Rev. at 681-82 (cited in note 9) (judge not proper party to represent the pro se litigant); Westling and Rasmussen, 16 Loy.U.Chi.L.J. at 310 (cited in note 25) (same).

${ }^{46}$ Wiggins, 465 U.S. at 178-79. 
In summary, many courts, including the Supreme Court, regard the Faretta dictum on procedural compliance as settled law. The Faretta approach preserves judicial impartiality and functions as an alternative means to court-appointed counsel to achieve this end. Thus, it should be settled law as regards pro se criminal defendants.

\section{Procedural Treatment of Pro Se Civil Litigants}

Requiring criminal defendants to comply strictly with procedural rules in federal court ${ }^{47}$ is justifiable because criminal defendants can, if this deters them from proceeding pro se, receive court appointed counsel in cases where they may be subject to imprisonment ${ }^{48}$ since the sixth amendment guarantees criminal defendants the right to counsel. ${ }^{49}$

The right to counsel is not absolute in civil cases, ${ }^{50}$ however. This poses an interesting problem. On the one hand, it has been suggested that the due process rights of civil litigants are not coterminous with those of criminal litigants simply because the interest in life or liberty is greater than the interest in property. ${ }^{51}$ Hence, appointing counsel for the indigent civil litigant only in some cases is justified..$^{52}$ On the other hand, the civil litigant who is denied court-appointed counsel and who cannot afford to hire a lawyer must represent himself in order to have his day in court. The "choice" to appear pro se may not truly be a choice under such circumstances. ${ }^{53}$ Most pro se appearances by civil litigants are

17 This comment will confine itself to a discussion of pro se litigation in federal court. Similar problems exist in state court as well. See Note, 96 Yale L.J. at $1641 \mathrm{n} .2$ (cited in note 5) (citing state laws on the right to self-representation).

48 Argersinger v. Hamlin, 407 U.S. 25 (1972); Scott v. Illinois, 440 U.S. 367 (1979).

40 "In all criminal prosecutions, the accused shall enjoy the right . . . to have the Assistance of Counsel for his defence."

U.S.Const. amend. VI.

so Lassiter v. Department of Social Services, 452 U.S. 18, $26-27$ (1981).

${ }^{\text {s1 }}$ See, e.g., Ake v. Oklahoma, 470 U.S. 68, 78 (1985) ("The private interest in the accuracy of a criminal proceeding that places an individual's life or liberty at risk is almost uniquely compelling"); Lassiter, 452 U.S. at 27 (recognizing a rebuttable presumption in every civil case that no due process right to counsel exists absent a potential deprivation of personal freedom). See also Note, Expanding the Due Process Rights of Indigent Litigants: Will Texaco Trickle Down?, 61 N.Y.U.L.Rev. 463, 496 (1986).

s2 Note, 61 N.Y.U.L.Rev. at 496-97. As discussed above, the Supreme Court held in Lassiter that a civil litigant's due process rights must be weighed against the presumption that, absent a potential deprivation of the litigant's personal freedom, there is no due process right to counsel.

ss Jacobsen, 790 F.2d at 1367-68 (Reinhardt dissenting). See generally Note, An Extension of the Right "of Access: The Pro Se Litigant's Right to Notification of the Requirements of the Summary Judgment Rule, 55 Fordham L.Rev. 1109, 1132-35 (1987). 
not voluntary but rather result because pro se litigants cannot afford attorneys to represent them. ${ }^{54}$ Some litigants, of course, will be able to get an attorney to take their case on a contingent fee basis. Many pro se civil cases, however, are civil rights cases or habeas corpus actions for injunctive relief which would not generate money judgments. ${ }^{\mathrm{ss}}$ Thus, we cannot do in this instance what Judge Richard Posner would have us do: subject the merits of every case to "the test of the market," litigant who cannot retain counsel does not have a meritorious case. $^{\text {.7 }}$

The effects of holding a pro se civil litigant to strict compliance with procedural rules under the Faretta approach are manifold. First, not only will this deter civil litigants from proceeding pro se, it also will deter those with meritorious claims who cannot get counsel from suing in the first place. If they do sue, their chances of winning are decreased. ${ }^{58}$ The result is to place in jeopardy the one due process right that pro se litigants clearly have: the right to a meaningful opportunity to be heard..$^{59}$

The second problem is that the judge who denies the pro se civil litigant's request for counsel under 28 U.S.C. $\S 1915(\mathrm{~d})$ is also the judge who will enforce that litigant's obligation to comply strictly with procedural rules. Like "cunning old Fury,"60 the judge will in a sense both specify and carry out the procedural program confronting the pro se litigant. Is it inequitable for a judge to deny a pro se civil litigant assistance of counsel and then refuse to exhibit some sort of leniency toward the pro se litigant in these matters? ${ }^{\text {B1 }}$

s4 Note, 55 Fordham L.Rev. at 1132, n.149; Robbins and Herman, 42 Brooklyn L.Rev. at 663 (cited in note 9).

ss Note, Pro Se Appeals in the Fifth Circuit: The Gradual Demise of the Notice Exception to Federal Rule of Appellate Procedure 4(a) and An Argument for Its Resurrection, 4 Rev. Litigation 71, 73 (1983).

${ }^{8 B}$ Merritt v. Faulkner, 697 F.2d 761, 769-70 (7th Cir. 1983) (Posner concurring and dissenting).

${ }^{87}$ In civil rights cases brought under 42 U.S.C. $\$ 1983$, attorney's fees are available to the plaintiff's attorney under 42 U.S.C. $\S 1988$ if the plaintiff prevails on the merits. The vast majority of $\S 1983$ cases are, however, dismissed before trial. Hence, this is not, as Posner suggests, an added incentive for attorneys to take civil pro se cases. Merritt, 697 F.2d at 770; Note, 55 Fordham L.Rev. at 1133-35, nn.162, 173-77 (cited in note 53).

${ }^{38}$ See text at note $24-26$.

s9 Logan v. Zimmerman Brush Co., 455 U.S. 422, 437 (1982). See also Little v. Streater, 452 U.S. 1, 5-6 (1981). See section III.B.1.

${ }^{80}$ Lewis Carroll, Alice's Adventures in Wonderland 40, in The Complete Works of Lewis Carroll (Modern Library ed. 1936).

61 Merritt, 697 F.2d at 769 (Posner concurring and dissenting) ("It is unfair to deny a 
This section first will explore some of the ways in which courts have treated pro se civil litigants. The vast number of pro se cases makes it necessary to cite only a few exemplary cases. Second, this section will discuss what judicial process should be due the pro se civil litigant in light of current due process jurisprudence. As it turns out, courts that deal with this problem on a case-by-case basis are on the right track. It is the spirit with which they now approach the due process inquiry that is sometimes wanting.

\section{A. Procedural Treatment of Pro Se Litigants in Civil Cases: A Look at The Status Quo}

The only across-the-board special treatment which the Supreme Court has guaranteed pro se litigants, apart from the due process rights accorded all litigants in civil cases, is the right to have courts liberally construe their pleadings. In Haines v. Kerner ${ }^{62}$ the plaintiff prisoner's complaint against state and prison officials alleged that he suffered physical injuries while in solitary confinement and a denial of due process in the steps leading to that confinement. The Supreme Court reversed a dismissal under Rule 12(b)(6) of the Federal Rules of Civil Procedure for failure to state a claim under 42 U.S.C. $\$ 1983$. The Court noted that:

[A]llegations such as those asserted by petitioner, however inartfully pleaded, are sufficient to call for the opportunity to offer supporting evidence. We cannot say with assurance that under the allegations of the pro se complaint, which we hold to less stringent standards than formal pleadings drafted by lawyers, it appears "beyond doubt that the plaintiff can prove no set of facts in support of his claim which would entitle him to relief."

On its face, the Haines rule is limited to construction of pleadings. It seems odd, however, to allow a litigant "an opportunity to offer proof"64 and then to enforce strict compliance with procedure thereafter. ${ }^{65}$ On the other hand, extending too much procedural leniency to a pro se litigant risks undermining the impartial role of the judge in the adversary system. ${ }^{66}$ The federal courts, which have

litigant a lawyer and then trip him up on technicalities.").

62404 U.S. 519 (1972).

os Id. at 520-21 (emphasis added), quoting Conley v. Gibson, 355 U.S. 41, 45-46 (1957).

os Haines, 404 U.S. at 521.

os Note, 55 Fordham L.Rev. at 1120-21 (cited in note 53).

${ }^{86} \mathrm{Id}$. at 1121-23. See also notes $43-45$ and accompanying text. 
approached this question largely on a case-by-case, rule-by-rule basis, are clearly wrestling with these conflicting notions. Some courts expand the Haines rationale into a general paternality towards the pro se civil litigant. ${ }^{67}$ Others, citing the nature of the adversary system as a bar to leniency, enforce compliance with procedural requirements by pro se litigants in civil cases.

In several cases, for instance, the federal courts have ruled that pro se litigants must receive notice of the requirements of a summary judgment motion under Rules 12(b)(6) and 56 of the Federal Rules of Civil Procedure. ${ }^{68}$ In Hudson v. Hardy, ${ }^{69}$ a pro se prisoner filed a "petition for writ of declaratory judgment," alleging cruel treatment by his jailors. The district court granted defendant's "motion to dismiss the complaint or, in the alternative, for summary judgment" without informing the plaintiff of the nature of a summary judgment motion and his obligation to respond thereto.

The District of Columbia Circuit reversed, holding that a pro se litigant against whom a summary judgment motion is made must be given notice of the requirement to respond to the motion in order that he might avoid having judgment automatically entered against him.70 This notice must be, the Court wrote, "understandable to one in appellant's [a pro se litigant's] circumstances fairly to apprise him of what is required." It must inform him not only of his obligation to respond but also of the consequences of not doing so. ${ }^{71}$

Courts have justified this guarantee of notice by the observation that summary judgment is "contrary to lay intuition."72 That is, most pro se litigants assume that all lawsuits proceed smoothly from complaint to answer to trial..$^{73}$ Hence, they do not know how or when to respond to the motion. For example, a pro se party may

Bz Id.

${ }^{68}$ See, e.g., Hudson v. Hardy, 412 F.2d 1091, 1094 (D.C.Cir. 1968); Garaux v. Pulley, 739 F.2d 437, 439 (9th Cir. 1984); Moore v. State of Fla., 703 F.2d 516, 520-21 (11th Cir. 1983); Ham v. Smith, 653 F.2d 628, 630 (D.C.Cir. 1981); Barker v. Norman, 651 F.2d 1107, 1128-30 (5th Cir. 1981); Roseboro v. Garrison, 528 F.2d 309, 310 (4th Cir. 1975); Mitchell v. Inman, 682 F.2d 886, 887 (11th Cir. 1982).

Bo 412 F.2d 1091 (D.C.Cir. 1968).

${ }^{70}$ Id. at 1092-94. See also cases cited in note 68.

${ }^{71}$ Hudson, 412 F.2d at 1094. See also Davis v. Zahradnick, 600 F.2d 458, 460 (4th Cir. 1979); Roseboro v. Garrison, 528 F.2d 309 (4th Cir. 1975).

72 Lewis v. Faulkner, 689 F.2d 100, 102 (7th Cir. 1982).

73 Jacobsen v. Filler, 790 F.2d 1362, 1368 (9th Cir. 1986) (Reinhardt dissenting); Zeigler and Hermann, 47 N.Y.U.L.Rev. at 202 (cited in note 2). 
assume he can address the motion at trial. ${ }^{74}$ Other procedural maneuvers are equally contrary to lay intuition. Courts therefore have extended the Hudson rationale to some of these, including service of process, ${ }^{75}$ status calls, ${ }^{76}$ and motions to dismiss. ${ }^{77}$

Other lower federal courts, however, have taken a Farettatype approach to ruling on procedural rights of pro se civil litigants. On the ground that judicial assistance to pro se litigants undermines the impartial role of the judge in the adversary system, at least one circuit court has ruled that the trial court did not have to notify a pro se plaintiff of a summary judgment motion's requirements. ${ }^{78}$ Courts have also denied judicial assistance and leniency to civil pro se litigants in the context of the amount-in-controversy requirement, ${ }^{78}$ pre-trial statements, ${ }^{80}$ appearance for depositions, ${ }^{81}$ appeal periods, ${ }^{82}$ and rules of evidence. ${ }^{83}$

Some courts have extended judicial assistance only to those pro se litigants who are prisoners. ${ }^{84}$ Prisoners, these courts claim, have problems extending beyond the mere inability to pay for counse $^{85}$ which justify the burden placed on the adversary system

74 Jacobsen, 790 F.2d at 1368 (Reinhardt dissenting).

${ }^{75}$ Borzeka v. Heckler, 739 F.2d 444 (9th Cir. 1984) (Fed.R.Civ.Proc. 4(d)(5), requiring personal service on an officer or agent of the United States when the United States is a party, should be given flexible construction in the case of a pro se litigant).

${ }^{78}$ Camps v. C \& P Tel. Co., 692 F.2d 120, 124-25 (D.C.Cir. 1981) (pro se plaintiff who showed up a few minutes late for status call should not have his case dismissed).

77 Mitchell v. Inman, 682 F.2d 886 (11th Cir. 1982) (pro se plaintiff should not have his case dismissed for failure to respond to motion to dismiss where he was not given notice of the need to respond thereto).

78 Jacobsen v. Filler, 790 F.2d 1362, 1365-66 (9th Cir. 1986).

79 Dozier v. Ford Motor Co., 702 F.2d 1189, 1194 (D.C.Cir. 1983) (refusing to allow plaintiff to refile his complaint to comply with the amount in controversy requirement).

so Burgs v. Sissel, 745 F.2d 526 (8th Cir. 1984) (pro se plaintiff's § 1983 complaint properly dismissed under Fed. R.Civ.Proc. 41(b) for failure to amend flawed pre-trial statement after three opportunities to comply with the district court's pretrial order).

s1 Hepperle v. Johnston, 590 F.2d 609 (5th Cir. 1979) (pro se plaintiff's repeated failure to appear for deposition justified dismissal under Fed.R.Civ.Proc. 41(b) after warning of possible dismissal).

${ }^{82}$ Martinez-McBean v. Government of Virgin Islands, 562 F.2d 908 (3d Cir. 1977) (if pro se plaintiff understood appeal procedures, district court may not grant relief from earlier order of dismissal).

s3 Andrews v. Bechtel Power Corp., 780 F.2d 124 (1st Cir. 1985) (pro se plaintiff cannot be exempted from requirements of Fed.R.Evid. 103(a)(2), which forbids the predication of error on evidence not actually offered at trial).

s4 See, e.g., Ham v. Smith, 653 F.2d 628, 630 (D.C. Cir. 1981); Hudson v. Hardy, 412 F.2d 1091, 1094-95 (D.C.Cir. 1968); Phillips v. United States Board of Parole, 352 F.2d 711, 714 (D.C.Cir. 1965); Lewis v. Faulkner, 689 F.2d 100, 102 (7th Cir. 1982); Wilborn v. Escalderon, 789 F.2d 1328, 1332 (9th Cir. 1986); Smart v. Villar, 547 F.2d 112, 114 (10th Cir. 1976); Moore v. State of Fla., 703 F.2d 516, 521 (11th Cir. 1983).

${ }^{85}$ Hudson, 412 F.2d at 1094. 
by treating them in a lenient manner. ${ }^{86}$ These problems include limited access to legal materials ${ }^{87}$ and sources of proof. ${ }^{88}$ In a similar vein, one appeals court has suggested limiting the Hudson approach to civil cases involving injunctive relief, as opposed to those involving monetary damages. ${ }^{89}$ This rule presumably is based on the inability of indigent litigants seeking declaratory or injunctive relief to obtain counsel even on a contingent fee basis.

Some courts have adopted both formal and informal procedures to be followed in pro se civil cases. ${ }^{90}$ For example, in the Fifth Circuit, procedures for dealing with prisoner civil rights cases include regulations facilitating the filing of complaints, without liability for court costs, by indigent persons; expansive construction of pleadings; provisions for supplementing the complaint, if necessary, by an auxiliary questionnaire so as to enable the court better to understand the pleadings; assistance with service of process; and rules enabling the court to refer cases to a magistrate for special consideration..$^{91}$ In several jurisdictions, courts use special law clerks to aid pro se litigants before the complaint is filed.92

The federal rules of practice for individual courts, however, offer little guidance to courts concerning how to rule on procedural issues in pro se cases. These rules are largely ministerial, pertaining to briefs, service of process, naming attorneys of record and the like. ${ }^{93}$ The Federal Judicial Center has promulgated guidelines for handling prisoner civil rights cases, most of which are pro se, in federal court. These guidelines contain suggested forms for courts to use, procedures for centralization of these cases in the district

${ }^{86}$ But see Jacobsen, 790 F.2d at 1367 (Reinhardt dissenting) (distinguishing between poor and imprisoned and those who merely are poor "creates two classes of indigent litigants, those who are poor and law abiding and those who are poor and not. It then affords lesser rights and protections to the former [class]."); Note, 55 Fordham L.Rev. at 1123 n.80 (cited in note 53) (calling this distinction "curious").

${ }^{87}$ Moore v. State of Fla., 703 F.2d 516, 520 (11th Cir. 1983).

${ }^{88}$ Hudson v. Hardy, 412 F.2d 1091, 1094 (D.C.Cir. 1968).

${ }^{89}$ Dozier v. Ford Motor Co., 702 F.2d 1189, 1194 (D.C.Cir. 1983).

${ }^{80}$ See Note, 55 Fordham L.Rev. at 1115 (cited in note 53).

91 Mitchell v. Beaubouef, 581 F.2d 412, 415-16 (5th Cir. 1978).

${ }^{92}$ Zeigler and Hermann, 47 N.Y.U.L.Rev. at 176-202, 239 and n.345 (cited in note 2)(Second, Third, Fourth, Fifth, Sixth, Seventh, and Tenth Circuits employ pro se law clerks on appeal).

${ }^{\text {93 }}$ See, e.g., Rules of the United States Courts in New York 110, 142 (2d Cir.); 159, 188, 207, 227 (S.D.N.Y. and E.D.N.Y.); 548, 585 (W.D.N.Y.) (2d ed. 1987); Rules of the United States Court of Appeals for the Fourth Circuit 6 (1982); Practitioner's Handbook For Appeals to the United States Court of Appeals for the Seventh Circuit 21-23, 115 (1981 ed.). See also 28 U.S.C. § 1915(d) (1982); Fed.R.App.Proc. 24 (both dealing with litigation in forma pauperis). But see Rules of the United States Court of Appeals for the Fifth Circuit 111-12 (1983) (discussing Local Rule 42 pertaining to dismissal of cases). 
courts, and rules for filing, dismissal, and service of complaints. They also discuss appointment of counsel, procedures for handling motions, dismissal for failure to prosecute, procedures following the filing of defendant's answer, the making of special reports by the defendant, the pretrial statement, and the evidentiary hearing. ${ }^{94}$ These guidelines are, however, very general. Ultimately, they require procedural rulings in individual cases. Moreover, by definition they are inapplicable to non-prisoner civil rights cases, although their rationale could be extended to other cases. Finally, it is unclear to what extent federal courts have adopted these recommendations. ${ }^{95}$

Commentators also have suggested many uniform approaches for courts to adopt in this area. Before the Supreme Court declared in Lassiter v. Dept. of Social Services ${ }^{98}$ that there is no absolute due process right to counsel in civil cases, the obvious solution, appointment of counsel, was proposed for civil pro se litigants. These commentators extended the logic of Powell v. Alabama, that the indigent criminal defendant has the right to counsel because he is unable adequately to defend himself, ${ }^{97}$ to pro se litigants in civil cases. Post-Lassiter commentators have proposed other, less expansive (and less expensive) solutions, such as legal education $^{98}$ and Hudson-type judicial notification to pro se litigants of procedural requirements. ${ }^{99}$

This comment proposes a solution that is rarely (and then, just barely) ${ }^{100}$ addressed by courts: use of a particularized due process balancing test to determine the procedural leniency due a pro se civil litigant in federal court simply because he is proceeding pro se. Unlike most comments, however, this one by-and-large supports the current treatment of pro se litigants in civil cases. What should be changed in many cases are the underlying presumptions

- Recommended Procedures at 45-106 (cited in note 24).

9s As of January, 1980, four circuits and several district courts had cited the previous edition of the Recommended Procedures. Id. at ix. See also Westling and Rasmussen, 16 Loy.U.Chi.L.J. at 299 n.152 (cited in note 25), for recent cases citing the Recommended Procedures. Use of the Recommended Procedures is not universal, and it is unclear whether the courts that do use them follow them chapter and verse.

96 452 U.S. 18 (1981).

${ }^{27}$ See Note, 96 Yale L.J. at 1641-42 and n.5 (cited in note 5). See also note 8 and the accompanying text above.

88 Id. at 1642. One former federal prisoner has written a book on suing pro se. See Daniel E. Manville, Prisoners' Self-Help Litigation Manual (rev. 2d ed. 1986).

99 Note, 55 Fordham L.Rev. 1109, 1128-37 (cited in note 53).

${ }^{100}$ Id. at 1115 n.38. See also unreported cases discussed in Robbins and Herman, 42 Brooklyn L.Rev. at 669 (cited in note 9). 
with which courts approach the procedural treatment question.

\section{B. Procedural Due Process Rights of Pro Se Civil Litigants}

Pro se litigants deserve, of course, the minimum due process rights to which all other litigants are entitled. The most significant of these rights is an opportunity to be heard, "granted at a meaningful time and in a meaningful manner."101 Other minimum due process protections include the requirement of adequate notice, the right to a neutral and detached decision maker, the right to hire counsel, the right to present evidence and confront and crossexamine witnesses, and the right not to be subjected to the jurisdiction or laws of a forum with which one has no significant contacts. ${ }^{102}$

As the Court noted in Logan v. Zimmerman Brush Co., however, not "every civil litigant [is entitled] to a hearing on the merits in every case." 103 The Court has maintained that "the very nature of due process negates any concept of inflexible procedures universally applicable to every imaginable situation." ${ }^{104}$ Due process is not "unrelated to time, place and circumstances," but rather is "flexible and calls for such procedural protections as the particular situation demands." 105

To this end, the Court has promulgated a balancing test requiring the weighing of private and governmental interests in order to determine how much judicial process is due. ${ }^{106}$ Applied on a case-by-case basis, such a balancing test is essentially a sliding scale. That is, some litigants will require very great procedural protections; others will require no protection; and the vast majority will receive an amount of protection somewhere in between.

At the risk of sounding tautological, a meaningful opportunity to be heard under the due process clause requires, therefore, an inquiry to determine how much further process is due under the facts and circumstances of the particular case. This comment concludes that, at a minimum, a civil pro se litigant is entitled to a liberal construction of his pleadings as is already required under

${ }^{101}$ Logan v. Zimmerman Brush Co., 455 U.S. 422, 437 (1982), quoting Armstrong v. Manzo, 380 U.S. 545, 552 (1965). See also Little v. Streater, 452 U.S. 1, 5-6 (1981).

${ }^{102}$ See Note, 61 N.Y.U.L.Rev. at 483 and n.166-72 (cited in note 51).

${ }^{103} 455$ U.S. 422,437 (1982).

104 Wolff v. McDonnell, 418 U.S. 539, 560 (1974), quoting Cafeteria Workers v. McElroy, 367 U.S. 886,895 (1961).

${ }^{105}$ Little, 452 U.S. at 5, quoting Joint Anti-Fascist Refugee Committee v. McGrath, 341

U.S. 123, 162 (1951), and Morrissey v. Brewer, 408 U.S. 471, 481 (1972).

${ }^{108}$ Mathews v. EIdridge, 424 U.S. 319, 335 (1976). 
Haines $v$. Kerner. ${ }^{107}$ This liberal construction will in turn facilitate the court's efforts to determine what further procedural protections the due process balancing test requires.

Procedural due process inquiries require a two-step analysis. The first step is identification of a protected interest of which the litigant otherwise would be deprived. The second step is a determination of what type of judicial process is due. ${ }^{108}$

1. Protected Interest. Civil litigants have a protected interest in a meaningful opportunity to be heard. This interest is analytically distinct from any protected liberty or property interests that may underlie the litigant's cause of action or legal defenses. ${ }^{109} \mathrm{Liti}$ gants have invoked the interest in a meaningful opportunity to be heard in order to gain access to the courts in the absence of any potential deprivation of an underlying substantive interest. ${ }^{110}$ This subsection argues that, regardless of whether there are protected liberty or property interests attached to a given pro se litigant's underlying claim, courts should hold that a meaningful opportunity to be heard is itself a protected interest for such litigants.

Authorities are split on whether there is a constitutional right to proceed pro se in civil cases. ${ }^{111}$ In fact, access to court is rarely unconditional where there are no fundamental constitutional rights at stake or there is no necessity to resort to the court system. ${ }^{112}$ Civil litigants, however, have a statutory right to proceed pro se under 28 U.S.C. $\S 1654$.

Although the government may not be required to give litigants access to court, case law indicates that once it does grant access, the procedures used must comport with due process. ${ }^{113}$ Moreover,

${ }^{107} 404$ U.S. 519 (1972).

${ }^{108}$ Logan, 455 U.S. at 428.

109 Laurence H. Tribe, American Constitutional Law $\S 10-18$ at 753-54 (2d ed. 1988).

${ }^{110}$ John E. Nowak, Ronald D. Rotunda, J. Nelson Young, Constitutional Law $\S 13.10$ at 517 (3d ed. 1986).

${ }_{111}$ See the cases cited in Note, 55 Fordham L.Rev. at 1109 n.3 (cited in note 53).

112 See United States v. Kras, 409 U.S. 434 (1973) (access to bankruptcy court could be denied to those who could not pay the $\$ 50$ filing fee because alternatives, such as settling one's debts out of court, exist); Logan v. Zimmerman Brush Co., 455 U.S. 422, 430 n.5 (1982) ("having made access to the courts an entitlement or a necessity, the State may not deprive someone of that access unless the balance of state and private interests favors the government scheme"). For an example of a fundamental right requiring access to the state court system, see Boddie v. Connecticut, 401 U.S. 371 (1971) (filing fee required to initiate a divorce action could not constitutionally be applied to indigents to keep them out of court because of freedom of choice in marital decisions).

${ }^{213}$ See, e.g., Evitts v. Lucey, 469 U.S. 387, 393 (1985) (states are not constitutionally required to grant an appeal as of right to a criminal defendant, but if the state has created appellate courts as an integral part of its justice system, the procedures in deciding appeals 
statutory interpretation supports this argument: Congress, after all, would not have granted the right to proceed pro se without conveying with that right a meaningful opportunity to be heard. Ordinarily, a denial of due process does not occur if a state restricts the right of access by means of reasonable procedural requirements. ${ }^{114}$ A litigant is denied due process, however, if these requirements work to deny him a meaningful opportunity to be heard. ${ }^{115}$

A refusal to construe pleadings flexibly, as required under Haines, is tantamount to withdrawal of that meaningful opportunity. For instance, an otherwise meritorious claim could be dismissed under Rule 12(b)(6) of the Federal Rules of Civil Procedure for failure to state a claim. The very point of the Haines approach is to determine if, when a pro se civil plaintiff has not said the "magic words" (or has said the wrong words), a cause of action exists. ${ }^{116}$ Even though the number of meritorious pro se complaints may be small, it is essential that these complaints be recognized. ${ }^{117}$ The protection of federal court litigants' interest in a meaningful opportunity to be heard while litigating is a central aspect of procedural due process.

2. What Process is Due. Once a protected interest is identified, courts must then determine how much process is due the civil pro se litigant. The Supreme Court in Mathews $v$. Eldridge promulgated its test for determining the procedural protections to which a litigant is entitled by due process. ${ }^{118}$ This test requires consideration of three factors:

must comport with due process); Nowak, Rotunda, Young, Constitutional Law $\S 13.10$ at 518 n.8 (cited in note 110).

114 Tribe, American Constitutional Law $\$ 10-18$ at 756 (cited in note 109), discussing Martinez v. California, 444 U.S. 277 (1980) (statute granting immunity from suit to state parole officials did not violate due process).

116 Boddie, 401 U.S. at 377-80; Walters v. Nat. Assn. of Radiation Survivors, 473 U.S. 305, 319-34 (1985) (plaintiff's interest in a "meaningful presentation," here alleged to be denied by an attorney fee limitation statute that deprived plaintiff of the right to be represented by counsel of his choice, was outweighed by the government's interests in having informal proceedings before the Veterans Administration and in preventing large portions of awards from going to attorneys). See discussion of the procedural due process determination at section III.B.2. See also Tribe, American Constitutional Law $\S 10-18$ at 753-60 (cited in note 109).

${ }^{116}$ See, e.g. Hansen v. May, 502 F.2d 728 (9th Cir. 1974) (pro se plaintiff's claim, styled one for "habeas corpus," should have been treated by lower court as stating a claim under $\S$ 1983). Some argue that, carried too far, the Haines approach will find a cause of action where none exists. See Justice Rehnquist's dissent in Hughes v. Rowe, 449 U.S. 5, 22-23 (1980).

${ }^{117}$ Westling and Rasmussen, 16 Loy.U.Chi.L.J. at 275, 303 (cited in note 25).

118424 U.S. 319 (1976). 
First, the private interest that will be affected by the official action; second, the risk of an erroneous deprivation of such interest through the procedures used, and the probable value, if any, of additional or substitute procedural safeguards; and finally, the Government's interest, including the function involved and the fiscal and administrative burdens that the additional or substitute procedural requirement would entail. ${ }^{119}$

As Judge Posner points out, this balancing test is no more than an application of the Learned Hand formula for negligence liability ${ }^{120}$ to the due process context. ${ }^{121}$ Hand's formula, $\mathrm{B}<\mathrm{PL}$, finds defendants liable for their negligent conduct when the burden of taking precautions (B) is less than the probability that accidents will otherwise occur (P) multiplied by the cost of accidents to the plaintiff $(\mathrm{L}){ }^{122}$ In the due process context, this formula should mean that the type of process due is that whereby the government's interest in not having such precautions (B) does not exceed the probability that error will otherwise occur $(P)$ multiplied by the value of the litigant's interest (L). As Posner suggests, the objective of a procedural system is to minimize both the cost of erroneous judicial decisions and the cost of operating the procedural system. In other words, if the cost of such error is less than the cost of reducing the error, then efficiency considerations tell us to tolerate the error. ${ }^{123}$

We now will consider whether due process requires use of the Haines approach in the case of a pro se civil litigant in light of these factors. Valuing the interests at stake is hard, naturally, because many of them cannot be measured in dollars and cents. For instance, what is the value of injunctive relief to a pro se plaintiff suing under 42 U.S.C. $\S 1983$ ? How, for that matter, does one place a numerical value on any intangible right? Can we assume that it is worth as much to the litigant as the money received by a plaintiff suing for damages? Even the amount received in a civil damage action will vary from case to case, so it is difficult to equate the two different forms of relief; some say impossible. ${ }^{124}$ Posner recognizes

110 Id. at 335.

${ }^{120}$ See United States v. Carroll Towing Co., 159 F.2d 169, 173 (2d Cir. 1947).

121 Richard A. Posner, Economic Analysis of Law $\$ 21.1$ at 517-18 (3d ed. 1986).

${ }^{122}$ Carroll Towing, 159 F.2d at 173. Posner, Economic Analysis of Law at $\S 21.1$ at 51718 (cited in note 121).

${ }^{123}$ See Posner, Economic Analysis of Law $\$ 21.1$ at 517-18 (cited in note 121).

124 One commentator dubs the Eldridge formula a "utilitarian calculus" and claims that the rule it yields is, in effect: "Void procedures for lack of due process only when alternative procedures would so substantially increase social welfare that their rejection seems irra- 
that these interests are hard to value and that what essentially are efficiency considerations have their limits as decision making criteria. He urges, however, that these factors be applied qualitatively as well as quantitatively. ${ }^{125}$ As it turns out, this is in fact what courts often do. ${ }^{126}$

a. The Pro Se Civil Litigant's Interest. The pro se civil litigant's constitutionally protected interest is in a meaningful opportunity to be heard. Obviously, valuation of this interest includes the value of the underlying substantive claim which he may be either prevented or deterred from bringing. It also includes the value of this opportunity itself. ${ }^{127}$

A meaningful opportunity to be heard is a core due process value. As discussed above, if one cannot proceed at all, one clearly has lost more than simply the damages or the injunctive relief sought because the meaningful opportunity to be heard is itself a protected interest. ${ }^{128}$

b. The Probability of Error. Needless to say, judicial resources should not be wasted on frivolous claims. Many pro se claims are in fact frivolous. ${ }^{129}$ Without liberal construction of pleadings under Haines, however, many meritorious complaints will not make it beyond the pleading stage. ${ }^{130}$ The Haines approach, then, is valuable in that it will reduce erroneous dismissal of claims to at least "normal" levels and will encourage pro se civil litigants to bring merito-

tional." Jerry L. Mashaw, The Supreme Court's Due Process Calculus For Administrative Adjudication in Mathews $v$. Eldridge: Three Factors in Search of a Theory of Value, 44 U.Chi.L.Rev. 28, 47-49 (1976).

125 Posner, Economic Analysis of Law $\S 21.1$ at 518 (cited in note 121).

${ }^{128}$ See, e.g., Little v. Streater, 452 U.S. 1, 13-14 (1981) (in deciding that application of statute charging blood test fees to requesting party in paternity actions denied indigent father due process of law, Court considered the importance of the parent-child relationship); Ake v. Oklahoma, 470 U.S. 68, 79-83 (1985) (in holding that indigent criminal defendants are entitled to court appointed psychiatrists where sanity at the time of offense is a major factor in the trial, Court discussed the value, in terms of enhancement of defendant's case, of such assistance). See also T. Alexander Aleinikoff, Constitutional Law in the Age of Balancing, 96 Yale L.J. 943, 975 n.203 (1987)("[In its constitutional cases, the Supreme] Court may talk about 'costs' and 'benefits' to give the impression that some agreed upon common scale is being used for weighing values, but the Court's analysis is decidedly noneconomic.").

${ }^{127}$ See Zeigler and Hermann, 47 N.Y.U.L.Rev. at 205-06 (cited in note 2) (pro se litigants deserve fair and efficient screening of their claims).

${ }^{128}$ See section III.B.1.

${ }^{129}$ See cases cited in Note, 55 Fordham L.Rev. at 1109 n. 4 (cited in note 53).

${ }^{130}$ See Westling and Rasmussen, 16 Loy.U.Chi.L.J. at 304-05 (cited in note 25) (tendency of courts to review the denial to proceed in forma pauperis and the resulting summary dismissal under 28 U.S.C. $\$ 1915$ (d) under the abuse of discretion standard; summary dismissal under $\S 1915$ (d) should instead be used sparingly in order to avoid dismissal of meritorious claims). 
rious claims.

c. The Government's Interests. The governmental interests in not having the pleadings of pro se civil litigants liberally construed are many. However, they do not outweigh in most cases the value to the civil pro se litigant of having such liberal construction under Haines.

The first governmental interest is, of course, conservation of judicial resources: time and money. There is no doubt about it: pro se litigants impose burdens, both temporally and financially, on the courts. ${ }^{131}$ All other litigants, however, cost the court time and money as well. ${ }^{132}$ The additional time and money required to give a liberal reading to pro se pleadings once one already has them in hand seems minimal.

The second governmental interest is in preserving the impartial role of the judge in the adversary system. This is an important interest, important enough to justify strict enforcement of compliance by pro se criminal defendants with procedural rules under Faretta and Wiggins. ${ }^{133}$ In the civil context, however, this argument proves too much. The effects of a Faretta approach in civil cases are deterrence of meritorious suits and hindrance of the pro se civil litigant who has difficulty complying with procedure because of his lack of knowledge. This point parallels the reasoning in Ake v. Oklahoma, where the Court noted that the state's interest in prevailing at trial in a criminal case is necessarily tempered by its interest in a fair and accurate adjudication of cases. ${ }^{134}$ Moreover, the actual burden imposed on the adversary system by Haines review is slight. The standard that a complaint should be dismissed only if it is "beyond doubt that the plaintiff can prove no set of facts in support of his claim which would entitle him to relief" originally was formulated in the context of litigants represented by counsel. ${ }^{135}$ Haines admittedly requires "less stringent standards"136 for review of pro se claims than of pleadings drafted by lawyers. The ultimate result is a less stringent interpretation of what is itself a very lax standard. The incremental adversarial cost,

131 See Note, 96 Yale L.J. at 1646 and n.31 (cited in note 5); Special Project, The Legal Services Corporation: Past, Present and Future, 28 N.Y.L.Sch.L.Rev. 593, 668-69 (1983).

${ }^{132}$ In 1980, for instance, the total budget for the United States Courts was $\$ 578,761,000$. Administrative Office of the United States Courts, 1980 Annual Report of the Director 28 (1980).

13s See section II.

1s4 470 U.S. 68,79 (1985).

${ }^{135}$ Conley v. Gibson, 355 U.S. 41, 45-46 (1957).

138 Haines, 404 U.S. at 520-21. 
therefore, appears minimal.

The final governmental interest is in reducing the great amount of frivolous pro se litigation. ${ }^{137}$ No one will deny that these cases are burdensome to the court system. ${ }^{138}$ This interest may be the most substantial of those discussed here. For the same reason the government should be interested in impartial justice for civil pro se litigants, however, it also should be interested in having meritorious civil pro se claims make it into court. ${ }^{139}$ Because the government is committed to ensuring that litigants have their day in court, the law should presume that the government's interest in ensuring court access outweighs the government's interest in the reduction of spurious suits that might result if courts did not liberally construe pleadings.

3. Toward a Due Process Standard for Leniency. In summary, pro se litigants in civil cases in federal court are entitled under the due process clause to have their pleadings liberally construed by the courts under the Haines $v$. Kerner standard. ${ }^{140}$ Thereafter, the same Eldridge factors used to reach this conclusion-the balancing of the values of private interests and procedural reform against the value of the government's interest in preserving the status quo-should be applied on a case-by-case basis to determine what further process is due. For the most part, things should go on as they did before: many cases still will be dismissed, a very few will have counsel appointed to represent the pro se litigant therein, and others will end up somewhere in between. Treatment of these other cases will include lenient application of all procedural rules whenever it is in the interest of due process to do so; forcing strict compliance with subsequent court procedures is inconsistent with a liberal construction of pleadings at the beginning of an action. It also will include the adoption of general rules-comparable to the Haines standard for review of pleadings-protecting the pro se civil litigant whenever the benefit of according such rules outweighs their cost under Eldridge.

What should change, however, is the spirit in which some

${ }^{137}$ See, e.g., Westling and Rasmussen, 16 Loy.U.Chi.L.J. at 291 n.108, 304 (cited in note 25) (only 4.9 percent of prisoner civil rights cases, $80-95$ percent of which were pro se in 1979, survive pretrial).

${ }^{138}$ See Note, 55 Fordham L.Rev. at 1109-10 n.4 (cited in note 53); Recommended Procedures at 9 (cited in note 24).

${ }^{139}$ See section III.B.2.c. See also Recommended Procedures at 11 (cited in note 24) (important to society, as well as to the individual, that meritorious complaints are found and dealt with).

140404 U.S. 519 (1972). 
courts construe these complaints. Regarding Haines as a particular product of a more generally applicable constitutional rule should encourage courts to reconsider the scope of their responsibilities. Courts should use the Haines standard, and not the Faretta standard, as the touchstone for evaluating procedural due process rights of civil pro se litigants. The background justification for the Faretta approach in criminal cases, the sixth amendment right to counsel, does not apply in civil cases.

Many pro se civil complaints will, as is proper, still be dismissed. On the other hand, the pro se civil litigant's lack of knowledge will retain its rightful place as a "shield" for him, and not become a "sword" for the court to use to deter him from suing or to defeat him in court if he does sue. A willingness to treat pro se litigants benevolently can alleviate a potentially unfair procedural system. ${ }^{141}$ In short, the Faretta approach, whereby pro se status implies no reprieve from with procedural requirements, ${ }^{142}$ while justified in criminal cases, should not be used to determine (or terminate) the procedural due process rights of civil pro se litigants.

\section{Conclusion}

The Supreme Court has mentioned in dicta in the criminal context that pro se status does not mean that a litigant is free to ignore relevant rules of procedural and substantive law. This position is justifiable in criminal cases on constitutional grounds.

It is not, however, justifiable in civil cases, where many litigants appear pro se not because they prefer to do so, but because they cannot afford counsel. Modern procedural due process jurisprudence requires, at the very least, that courts should give the pro se civil litigant a liberal construction of his pleadings. The court should then determine what further process is due, based on the individual facts and circumstances of the case. In short, in civil cases, there sometimes may be a "license not to comply" with procedural requirements.

${ }^{241}$ Robbins and Herman, 42 Brooklyn L.Rev. at 667 (cited in note 9).

142 Faretta, 422 U.S. at 835 n.46. 